\title{
ASSESSMENT OF DIRECTION FOR COORDINATION OF MONETARY REGULATION OF INVESTMENT IN THE INTEGRATION UNIONS
}

\author{
OCENA KIERUNKU POLITYKI MONETARNEJ \\ SŁUŻĄCEJ KOORDYNACJI INWESTYCJI W UNII INTEGRACYJNEJ
}

https://doi.org/10.34739/zn.2020.53.03

\author{
Marina Zelenkevich ${ }^{1}$, Natallia Bandarenka ${ }^{2}$ \\ ${ }^{1}$ Belarus, School of Business of Belarussian State University \\ e-mail: marina.zelenkevich@gmail.com, ORCID: 0000-0002-2964-7508 \\ ${ }^{2}$ Belarus, School of Business of Belarussian State University \\ e-mail: bondnata@mail.ru, ORCID: 0000-0002-1482-8429
}

\begin{abstract}
In the context of globalization and regionalization, central banks pursuing monetary policy in the country at the same time become subjects of monetary regulation within the framework of the integrational associations of which they are members. The purpose of the article is to assess the impact of monetary policy on investment and economic growth in integration unions and determine the appropriateness of their coordination. To achieve the goal, a method of correlation-regression analysis is proposed, one which allows for the identifying and assessing of the degree of influence of certain directions of monetary policy of the countries of the integration association on the indicators of investment and economic growth. As a result of the analysis, the expediency of coordination and implementation of a coordinated policy of central banks to stimulate the deposit and credit policy of commercial banks was proved, which positively affects the characteristics of supply and demand in the integrated investment market. The assessment of the directions of the coordination of monetary investments regulation was carried out on the example of an integration association - the Union of Belarus and Russia and can be extended to other integration associations with the participation of Belarus, in particular, to the monetary interaction of countries within the Eurasian Economic Union. The analysis is based on the statistical data of the National Statistical Committee and the National Bank of the Republic Belarus, the EAEU Department of Statistics, as well as statistical information from the Central Bank of Russia and the Union of Russia and Belarus.
\end{abstract}

Key words: investments, economic growth, monetary regulation, integration association, banking system, credit/ deposit policy

Streszczenie: W kontekście globalizacji i regionalizacji banki centralne prowadzące politykę pieniężną w kraju stają się jednocześnie podmiotami regulacji monetarnej w ramach zrzeszeń integracyjnych, których są członkami. Celem artykułu jest ocena wpływu polityki pieniężnej na inwestycje i wzrost gospodarczy w związkach integracyjnych oraz określenie zasadności ich koordynacji. W tym celu proponuje się metodę analizy korelacyjno-regresyjnej, która pozwala na identyfikację i ocenę stopnia wpływu określonych kierunków polityki pieniężnej krajów zrzeszenia integracyjnego na wskaźniki inwestycji i wzrostu gospodarczego. W wyniku przeprowadzonej analizy wykazano celowość koordynacji i realizacji skoordynowanej polityki banków centralnych w zakresie stymulowania polityki depozytowo-kredytowej banków komercyjnych, co pozytywnie wpływa na charakterystykę podaży i popytu na zintegrowanym rynku inwestycyjnym. Ocenę kierunków koordynacji regulacji inwestycji pieniężnych przeprowadzono na przykładzie stowarzyszenia integracyjnego Związek Białorusi i Rosji i można ją rozszerzyć na inne stowarzyszenia integracyjne z udziałem Białorusi, w szczególności na interakcję walutową krajów należących do Euroazjatyckiej Unii Gospodarczej. Analiza oparta jest na danych statystycznych Narodowego Komitetu Statystycznego i Narodowego Banku Republiki Białoruś, a także informacji statystycznych z Centralnego Banku Rosji i Związku Rosji i Białorusi.

Słowa kluczowe: inwestycje, wzrost gospodarczy, polityka monetarna, stowarzyszenie integracyjne, system bankowy, polityka kredytowa/depozytowa 


\section{Introduction}

The Union State (US) of Belarus and Russia is the most developed integration association with the participation of Belarus, the goals of which are the formation of a common economic space, and the implementation of a common social and foreign policy. For more than twenty years, particular attention in the formation and implementation of economic policy in the US was paid to a harmonization of the conditions for the activities of business entities in Belarus and Russia, so as to ensure the free movement of goods and services, labor resources and capital. Since then, significant progress has been achieved in unifying the principles, mechanisms and instruments of economic and social policy.

The monetary policy of the central bank is aimed at the investment process developing and ensuring sustainable economic growth, since it contributes to the formation of investment sources and their optimal distribution. In addition, monetary policy has a number of advantages which include flexibility and efficiency in its implementation. To date, within the framework of the US, the convergence of monetary regulation has been achieved in many of its parameters. So, for example, the directions of coordination of targets and the main instruments of monetary policy of central banks were determined which include operations on the open market, interest rates, required reserves, and refinancing of banks. For a long time Russia performed the functions of a strategic investor for Belarus, as a result of which the capital of Belarusian banks was formed. So to date (as of 01.01.2020), according to the rating agency Expert RA, $25 \%$ of the assets of the banking sector in Belarus were held by banks with Russian capital (Belgazprombank, Alfa-Bank, BPS-Sberbank, VTB Bank Belarus, BelVEB). According to the National Statistical Committee of the Republic of Belarus and the Ministry of Finance, in 2019 alone, the country received \$ 2.87 billion in direct investment from Russia, or almost $40 \%$ of the total ( $\$ 7.2$ billion) (National Statistical Committee...). In the context of the established close economic and financial interaction between the two countries, there is an objective need to identify promising areas for coordinating investment policy in an integration association using the mechanism of monetary regulation and substantiating general trends in the formation of a coordinated policy of central banks.

\section{Literature review}

In the context of globalization, central banks perform two main functions. On the one hand, they conduct monetary policy in the country, and on the other hand, they become subjects of monetary regulation within the framework of integration associations of which they are members (Navoy, 2013). In this regard, the issue of coordination and implementation of a coordinated policy of central banks to stimulate the deposit and credit policy of commercial banks becomes relevant (Korishchenko, Morozov, Bryanov, 2018).

For more than twenty years of the existence of the Union State of Russia and Belarus, particular attention was paid to the harmonization of the conditions of economic entities activity of the countries (Rekeda, 2019). Since then, significant progress has been achieved in unifying the principles, mechanisms and instruments of economic and social policy of the two countries, as well as the convergence of monetary regulation in many of its parameters. In this regard, the issues of the degree of influence of financial indicators on macroeconomic indicators of economic growth and investment activity arises (Zelenkevich, Bandarenka, 2020). To identify the intensity of dependences of macroeconomic indicators of economic growth on the instruments of monetary regulation of central banks, it is advisable to apply the method of correlation-regression analysis (Borovikov, 2003).

\section{Materials and methods}

To carry out this research, a set of methods was used that made it possible to achieve the research goal. The research method applied in the study was an overview of domestic and foreign specialist literature and Internet resources. The article uses compact and periodical publications, government documents, statistical materials, and internet sources. The practical part of the research is based on the data of the National Statistical Committee of the Republic of Belarus, the EAEU Department of Statistics, as well as statistical information from the Central Bank of Russia and the Union of Russia and Belarus. The study also applied the main provisions and basic principles of the System of National Accounts.

In order to analyze the influence of financial indicators on macro-indicators of economic growth correlation and regression analysis was used. For the best visual presentation of the results of the study the authors used tabular and graphical methods. 


\section{Methodological substantiation of the choice of indicators for correlation-regression models}

The real processes of formation and change in the volume and directions of investment occur with the direct participation of the state including the process of implementing monetary policy. At the same time they are largely due to the technological, institutional and organizational features of the production development in individual countries. This forms the specific features of the implementation of the monetary regulation of investments. To identify the intensity of dependencies of macroeconomic indicators which reflect the implementation of the investment process in the national economy, on the one hand, and the directions of monetary regulation of central banks to stimulate investment, on the other, it is advisable to apply the method of correlationregression analysis This method will reveal the relationship between the above groups of indicators in the two countries and compare the results. This will then make it possible to determine the directions of the coordination of monetary policy in order to stimulate mutual investments and increase their efficiency in the integration association.

As a source of information, the data provided by the Interstate Statistical Committee of the Commonwealth of Independent States (CIS STAT) for 1991-2018, the National Statistical Committee of the Republic of Belarus and the National Bank of the Republic of Belarus for 2000-2018 were used. The proposed time interval is significant for the implementation of the research goal and the obtaining of objective results, since it makes it possible to assess the state of the economy over a long period which reflects the periods of its growth and crisis phenomena. Based on the available initial data using the MS Excel and the STATISTICA (Borovikov, 2003) regression equations were constructed and analyzed as an imperative basis for the assessment.

At the first stage of the analysis, macroeconomic and monetary indicators were selected based on the application of logical methods of scientific analysis. The economic literature widely presents and substantiates those indicators that are used in world practice in order to assess the current state of the economy. One indicator that reflects changes and explains them from a macroeconomic standpoint is primarily the gross domestic product (GDP), which measures the income of all firms and households. GDP is often featured in statistical reports as it is regarded as the simplest indicator of a country's economic well-being. It is an indicator of the productive activity of a country based on a geographic criterion and equal to the sum of added values created by factors of production (both local and foreign) in the country (Burda, Viplosh, 1998). Another indicator that characterizes the economic development of a country is the gross national income (GNI). In contrast to the concept of GDP based on geographic location, the concept of GNI represents the value added by all factors of production owned by the residents of a given country, both domestically and abroad including income or value added generated by residents abroad (Burda, Viplosh, 1998).

According to the National Statistical Committee of the Republic of Belarus methodology, GNI is the sum of the primary income received by residents, taking into account the balance of primary income from abroad. According to the authors, it is GNI that is more correct compared to GDP for this study, since, along with domestic income, it includes the balance of wages from abroad, as well as the balance of direct, portfolio and other investment revenues from abroad (National Statistical Committee, 2015). Thus, according to the data of the Republic of Belarus, we choose the GNI indicator as an endogenous factor $(Y)$. In addition to $\mathrm{GNI}$, the indicators of gross savings and fixed capital investment were chosen as additional endogenous factors. Gross saving is the difference between $\mathrm{GNI}$ and total sums of private and public consumption. Investments in fixed capital contribute to the purchase, creation and expansion of the fixed assets of organizations, resulting in the construction of new facilities, the repair and modernization of equipment, the purchase of vehicles and real estate and other objects necessary for the enterprise's activity. In a developing economy bank loans remain the main external source of investment financing for a long time, since other forms of investment resources are used insufficiently, and this is due to the low level of development of the securities market.

The following indicators were chosen as an exogenous variable $(Y)$ for Russia: gross domestic product, gross savings, fixed capital investment and gross accumulation. Under the System of National Accounts (SNA), gross accumulation includes gross fixed capital formation, changes in inventories and net acquisition of values. Gross fixed capital formation is defined as resident unit investment in fixed assets with the purpose to create new incomes in future by using those in production. The second component of gross accumulation is changes in inventories. Changes in inventories comprise changes in productive stocks, work-in-process, finished products, and products for resale. We believe that the content of the indicator "gross accumulation" which 
essentially reflects the volume of fixed capital investments, with a focus on future income, can be used in regression models as an indicator of the investment process in the country.

As the influencing factors $(x)$ of the regression models, the authors chose monetary indicators that satisfied two main conditions: on the one hand, they are reflected in the official statistics of Russia and Belarus for a long period of time, and on the other hand, these indicators characterize individual instruments and objects of monetary regulation of two countries. These are the refinancing rates of the Central Bank of the Russian Federation and the National Bank of the Republic of Belarus, as well as indicators reflecting the volumes of deposits and loans to the economies of both countries.

\section{Assessment of the impact of the refinancing rate on economic growth indicators}

At the second stage of the analysis, a correlationregression analysis was carried out where the monetary policy instrument - the refinancing rate (in Russia - this is the key rate) was chosen as the exogenous variable " $x$ ". The refinancing rate (the key rate in Russia) is the interest rate at which the central bank provides loans to second-tier banks. The refinancing rate refers to the market instruments of monetary policy and is indicative in nature, serving as a signal for market participants. By determining the type of monetary policy the central bank thereby has an indirect impact on the behavior of the money market subjects. An increase in the refinancing rate in the system of restrictive policy measures leads to a decrease in the business activity of market entities and is used as a means of reducing inflation. The expansionary monetary policy in the system of applied instruments includes a reduction in the refinancing rate. The refinancing rate level differs from country to country and depends on the general economic condition and objectives of monetary policy. It is focused on such macroeconomic and monetary parameters, such as: dynamics of real GDP; inflation rate; the rate of devaluation and indicators of the state of the foreign exchange market (foreign exchange transactions of the population, business entities, the central bank); interest rates on bank loans and deposits and growth (decrease) rates of nominal and real volumes of loans and deposits; the volume of the ruble money supply, the volume of issued securities; interest rates in the interbank market. When determining the value of the refinancing rate other factors that are not subject to digital calculation are taken into account: the socioeconomic and political situation in the country, the expectations of the population, etc. This instrument is used in Russia and Belarus to solve short-term problems of regulating liquidity in the money market and reducing inflation.

The need to include this indicator in the number of exogenous variables is based on the assumption of the presence of its indirect influence (that is, influence through interest rates in the deposit and credit market) on the dynamics of investments and economic growth.

According to the results of the correlationregression analysis based on the data of the Republic of Belarus the refinancing rate was excluded from the analysis, since the degree of its influence on GNI was insignificant (determination coefficient $37.8 \%$ ). The obtained result proves that this indicator is used by the National Bank of the Republic of Belarus primarily as a means of reducing inflation for short-term purposes of regulating liquidity in the money market. In the medium and long term this variable indirectly contributes to the recovery of the economic situation in the country influencing liquidity in the money market and interest rates in the deposit and credit market. No significant dependence of GNI on the refinancing rate of the National Bank of the Republic of Belarus was found; which reflects the non-investment nature of this instrument.

In order to determine the dependencies between GDP and the refinancing rate of Russia, correlation models were built; as a result of which, the following results were obtained: the refinancing rate and GDP are statistically linked (the correlation coefficient is 0.61). A similar situation is observed when calculating the modified correlation coefficient for the refinancing rate $(x)$ and the fixed capital investments $(R=-0.57)$, the refinancing rate $(x)$ and gross savings $(Y)(R=-0.51)$ and the refinancing rate $(x)$ and gross accumulation $(Y)(R=-0.39)$. The obtained values of the coefficients indicate the existence of the dependence of the effective factor (GDP) on the exogenous indicator (the refinancing rate), nevertheless, they do not allow building a qualitative regression model.

Consequently, the data obtained for Belarus and Russia give grounds to conclude that there is no significant relationship between the refinancing rate as an instrument of monetary policy and indicators of economic growth and investment. Thus, the refinancing rate is not used as a tool for coordinating monetary policy in the direction of stimulating investment in the Union.

The tendencies for the convergence of this indicator in Belarus and Russia are dictated by the process of unification of the monetary systems of the two countries as the basis for the formation of a common economic and financial space. The refinancing rate tendency in Russia and Belarus for 2000-2019 is shown in Figure 1. 


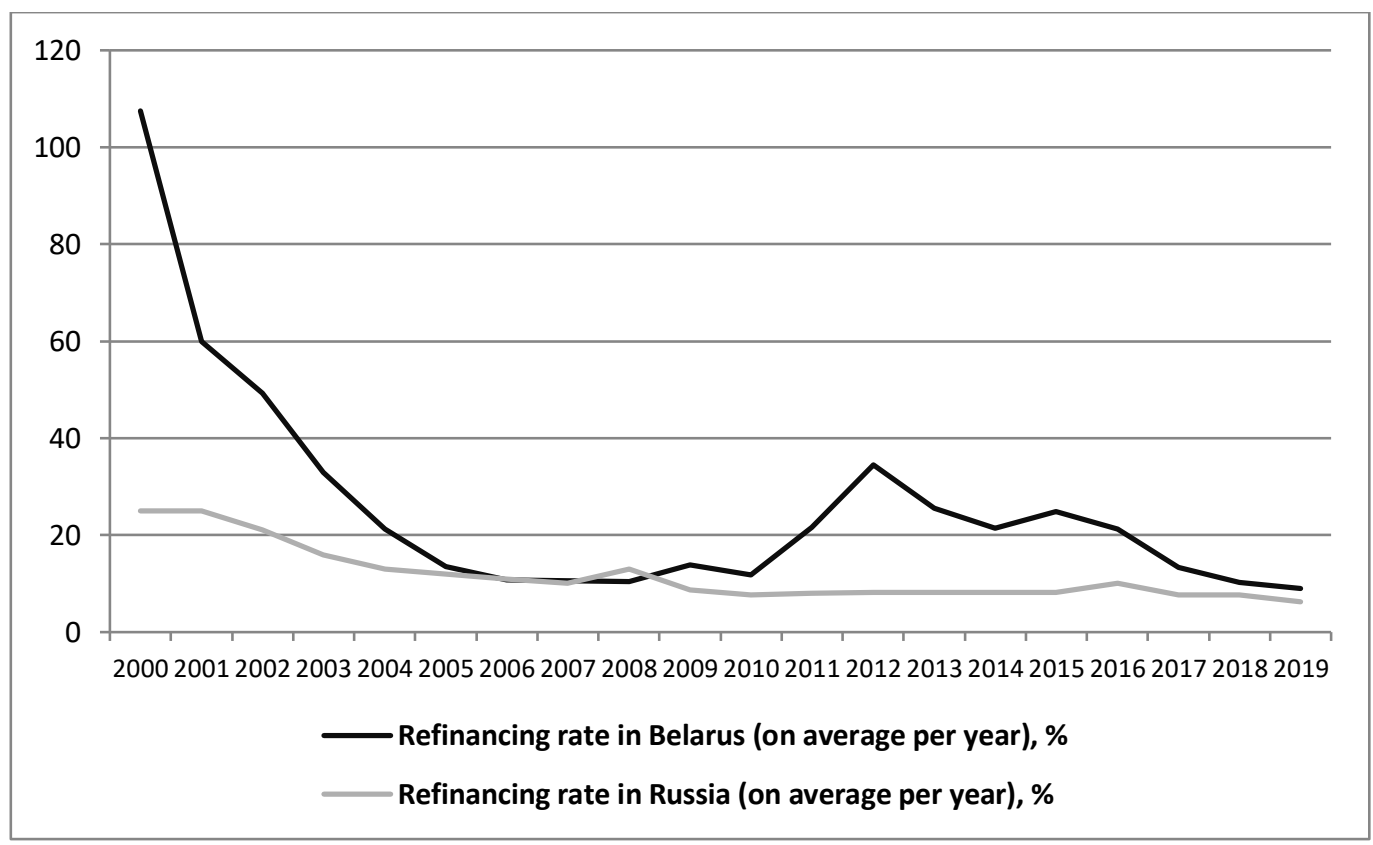

Figure 1. The trends in the refinancing rate in Belarus and Russia for 2000-2019

Source: Twenty-five years of the Commonwealth of Independent States 1991-2015: Statistical Book.

Interstate Statistical Committee of the CIS, 2016; Finances of the Commonwealth of Independent States 2014-2018:

Statistical Book. Interstate Statistical Committee of the CIS, 2019.

\section{Assessment of household savings impact on economic growth and investment indicators}

At the third stage of the research, the dependence of economic growth indicators and investment process indicators on the volume of individuals' deposits was studied. It is generally argued that deposits of individuals, being one of the forms of a population's savings, play an important role in the formation of investment resources. Thus, the influence of the population's savings on various aspects of the economy and finance is noted: "Firstly, it has a direct impact on the formation of current and future demand and, thus, on macroeconomic dynamics. Secondly, since the funds saved are withdrawn from circulation (in this case, most often they change their form), this leads to a change in the structure of the money supply, slows down the velocity of money circulation and reduces its inflationary potential. Third, the decisions made by households regarding the structure of generated savings determine what part of them will be created in an organized form and, therefore, can be transformed into investment and consumer loans" (Rumas, Pleshkun, 2006) And so, a population's savings are in the sphere of interests

1 On guaranteed reimbursement of bank deposits of individuals: Law of the Republic of Belarus, July 8, 2008 No. 369-3.- Mode of access: http://www.nbrb.by/legislation/ documents/l_369-z.pdf. On guarantees of safety of funds of individuals placed on accounts and (or) in bank deposits: of several economic groups: population, monetary authorities, and banks.

The forms of a population's savings are diverse and depend on many factors such as the level of economic and financial development, political stability, incomes, population preferences, national traditions, expectations, and others. In the 90s. in Belarus and Russia the main form of savings was the purchase of assets such as foreign exchange and real estate. Since mid-2000 there has been a positive dynamics in the volume of non-cash forms of savings: bank deposits which indicates an increase in public confidence in the banking system. These dynamics continued in the country until the crisis of 2011 when there was a massive withdrawal of money from their banks. This year the volume of individual deposits in Belarusian banks decreased by 13.7 percent (Yearbook of Banking statistics 2018). Subsequently, deposit growth recovered and has continued to this day. This can be seen as a positive result of the measures implemented by the Government and the National Bank to stimulate the attraction of the population savings to bank deposits. First of all, this is the establishment of state guarantees for the return of deposits ${ }^{1}$, the

Decree of the President of the Republic of Belarus, November 4, 2008, No. 22 with amendment. and add. dated June 29, 2017 No. 3. - Mode of access: http://www.nbrb.by/ legislation/documents/d22_3.pdf. 
proposal of new banking products that combine the savings and transactional functions of deposits, etc.

The influence of individual deposits $(x)$ on the gross national income $(Y)$ of the Republic of Belarus is characterized by the regression equation (1):

$$
Y=1032.54+2.780 x_{1}
$$

Equation (1) is significant according to Fisher's criterion and also has a high coefficient of determination $(\mathrm{R} 2=0.794)$. The regression coefficient is significant in accordance with the Student's t-test, but there is autocorrelation in the residuals. After eliminating autocorrelation by the ordinary least squares method the quality of the equation turned out to be unsatisfactory. For this reason equation (1) was not used in further analysis. In other words, the correlation-regression analysis showed the presence of a significant correlation between the volume of deposits of individuals and the value of the gross national income of Belarus, however, the exact parameters of this correlation cannot be presented.

The obtained result, according to the authors, is not accidental, since it has a methodological and practical basis. Analysis of scientific publications has shown that in the modern economic system the traditional function of banks as financial intermediaries is changing. This function operates when savings from depositors are transformed into credit resources and transferred to borrowers for the purpose of productive use for temporary use. Banks lend to organizations; and the population, which in this process are both suppliers of credit resources while creating deposits, and borrowers. As is known from theory, in the process of organizing lending the bank forms a source of credit resources (deposits), the volume of which increases and reflects the process of multiplicative expansion of the money supply.

In modern economic systems the intermediary function of banks has gradually transformed into a credit and deposit function. At the same time, Central Banks regulate the lending activity of banks in order to increase their investment orientation, forming the rules of the game and corresponding incentives in the credit market. Encouraging banks to attract household savings is also an important task for the central bank. However, in developing economies with a low level of income compared to developed countries, as well as an insufficient level of development of the non-banking segment of the financial structure, the population does not have a material basis and a wide choice of forms of savings other than bank deposits.

In the modern banking practice of Belarus, the mechanism for stimulating deposits of the population has certain disadvantages. First of all, this refers to the existing system of the taxation of income from deposits of individuals ${ }^{2}$ which, in our opinion, need to be improved in the direction of its liberalization and differentiation of tax rates for different types and volumes of deposits.

Correlation-regression analysis of the influence of individual deposits on macroeconomic indicators in the Russian Federation showed that the modified Pearson correlation coefficient is:

- for the dependence of GDP on deposits: 0.96;

- for the dependence of fixed capital investments on deposits: 0.91 ;

- for the dependence of gross savings on deposits: 0.75 ;

- for the dependence of gross accumulation on deposits: 0.79 .

The data obtained prove the existence of close links between the investigated parameters of the model. However, when constructing regression equations it is revealed that the parameters of the models do not correspond to some of the criteria that guarantee their quality. The methods for eliminating these shortcomings used in the analysis did not lead to the desired results, and therefore it was not possible to correctly and qualitatively assess the intensity of the dependences.

Thus, the results of the analysis of macroeconomic indicators for the factor "deposits of individuals" in the two countries showed that there is a close link between the parameters of the constructed models. Despite the lack of a qualitative intensity of dependence we believe that the obtained results provide a basis for coordinating individual directions of stimulating the banks deposit policy in Belarus and Russia in order to form investment resources. The actions of the central banks of the two countries in this direction include, first of all, activity on the formation of unified regulatory and institutional conditions for stimulating deposits of the population in the integration union.

\footnotetext{
${ }^{2}$ On attracting funds to deposits: Decree of the President of the Republic of Belarus, No. 7 of November 11, 2015 Access mode: http://president.gov.by/ru/official_
} 


\section{Assessment of the impact of loans on indicators of economic growth and investment}

At the fourth stage of the study, the dependence of the indicator of economic growth $(\mathrm{Y})$ on the indicator "volume of loans to the economy" which appears as an exogenous successor ( $x$ ) was determined. Central banks, as you know, influence this indicator with the help of various tools: the volume of refinancing, interest rates on the deposit and credit market, various forms of government support for banks' lending activities.

Statistical data on the volume of loans in the Republic of Belarus are presented in published statistical books as the following indicators: the volume of short-term loans and long-term loans to the economy. The authors carried out a correlation-regression analysis of the dependence of $\mathrm{GNI}$ on these indicators.

The dependence of GNI ( $Y$ ) on the volume of short-term loans $\left(x_{1}\right)$ is characterized by the equation (2) that is significant according to Fisher's criterion, has a high explanatory power (85.4\%):

$$
\begin{gathered}
Y=679.25+6.326 x_{1} \\
t(17)=7.0629 .97
\end{gathered}
$$

According to the equation (2), the volume of shortterm loans forms a significant share of GNI: the absence of short-term loans will ensure the value of the gross national income at the level of 679.25 million rubles. With an increase in the volume of short-term loans by 1 million rubles, GNI will increase by an average of 6.33 million rubles, or an increase in the volume of short-term loans by $1 \%$ will lead to an increase in GNI by an average of $0.57 \%$.

The influence of the volume of long-term loans $\left(x_{1}\right)$ on $\mathrm{GNI}(Y)$ is characterized by the equation (3):

$$
\begin{gathered}
Y=1230.23+1.195 x_{1} \\
t(17)=12.67 \quad 5.19
\end{gathered}
$$

According to the equation (3), if the volume of long-term loans increase by 1 million rubles $\mathrm{GNI}$ will increase on average by 1.195 million rubles. Other words, an increase in the volume of longterm loans by $1 \%$ will lead to an increase in GNI by an average of $0.26 \%$.

The results of the correlation-regression analysis of the impact of short-term and long-term loans show their significant impact on the GNI of the Republic of Belarus. The significance of the impact of loans on the GNI in Belarus is also confirmed.

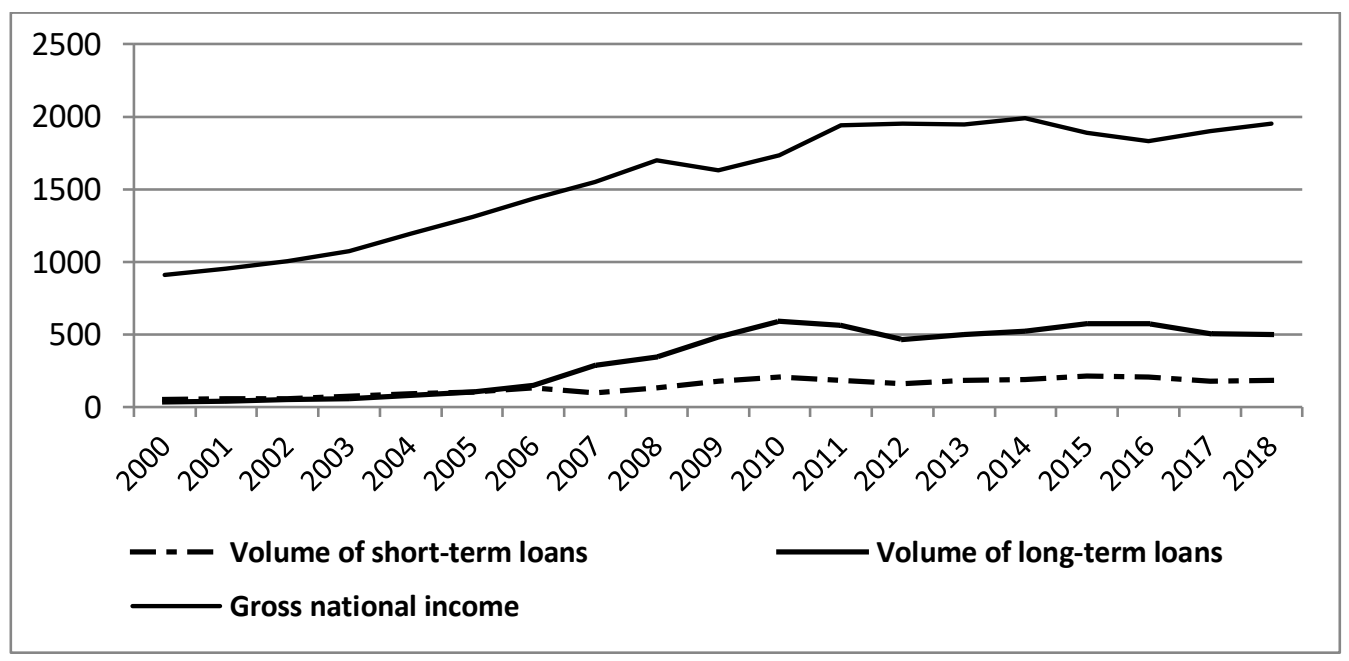

Figure 2. Gross national income and volume of loans in Belarus for 2000-2018 (in comparable prices 2000, million rubles) Source: own calculation on the basis of data of National Statistical Committee of the Republic of Belarus.

Figure 2 reflects the close dependence of GNI on the volume of short-term and long-term loans. Long-term loans, as a rule, are of an investment nature both for the population (this is primarily mortgage lending) and for organizations (loans for the modernization of production, the creation of new industries, the introduction of innovations, etc.).

Thus, the Central Bank acts to regulate the goals, methods and directions of investment lending to commercial banks appears to be the most effective form of stimulating investment in Belarus. The results of the correlation and regression analysis of the impact of loans on the gross national income of the Republic of Belarus are presented in Table 1. A similar analysis was carried out in Table 2. 
Table 1. The correlation and regression analysis results of the impact of loans on the gross national income of the Republic of Belarus

\begin{tabular}{cccccc}
\hline $\begin{array}{c}\text { Exogenous } \\
\text { variable }\end{array}$ & Equation & $\begin{array}{c}\text { Coefficient of } \\
\text { determination }\end{array}$ & $\begin{array}{c}\text { Darbin-Watson } \\
\text { Criterion }\end{array}$ & F-criterion & $\begin{array}{c}\text { Coefficient } \\
\text { of elasticity }\end{array}$ \\
\hline $\begin{array}{c}\text { Short-terms } \\
\text { loans }\end{array}$ & $Y=679.25+6.33 x_{1}$ & $R^{2}=0.854$ & 1.418 & 99.42 & 0.57 \\
Long-terms loans & $Y=1230.23+1.195 x_{1}$ & $R^{2}=0.783$ & 1.574 & 26.89 & 0.26 \\
\hline
\end{tabular}

Source: own calculation on the basis of research results.

Table 2. The correlation and regression analysis results of the impact of loans on gross savings in the Republic of Belarus

\begin{tabular}{cccccc}
\hline $\begin{array}{c}\text { Exogenous } \\
\text { variable }\end{array}$ & Equation & $\begin{array}{c}\text { Coefficient of } \\
\text { determination }\end{array}$ & $\begin{array}{c}\text { Darbin-Watson } \\
\text { Criterion }\end{array}$ & F-criterion & $\begin{array}{c}\text { Coefficient } \\
\text { of elasticity }\end{array}$ \\
\hline $\begin{array}{c}\text { Short-terms } \\
\text { loans }\end{array}$ & $Y=127.69+2.27 x_{1}$ & $R^{2}=0.778$ & 1.315 & 59.51 & 0.72 \\
Long-terms loans & $Y=301.81+0.43 x_{1}$ & $R^{2}=0.5612$ & 1.657 & 20.90 & 0.33 \\
\hline
\end{tabular}

Source: own calculation on the basis of research results.

As shown data in Tables 1 and 2 the volume of loans to the economy in Belarus affects both endogenous indicators - GNI and gross savings; however, the intensity of influence (elasticity coefficient) is higher if the indicator of gross savings is used as an endogenous variable.

After the authors identified a significant degree of influence of the volume of short-term and long- term loans on macroeconomic indicators in the Republic of Belarus, they chose to analyze the presence (or absence) of the same correlation in Russia. Figure 3 shows that the changes of the macroeconomic indicators characterize the investment process, and that the volume of loans in Russian Federation have a similar tendency.

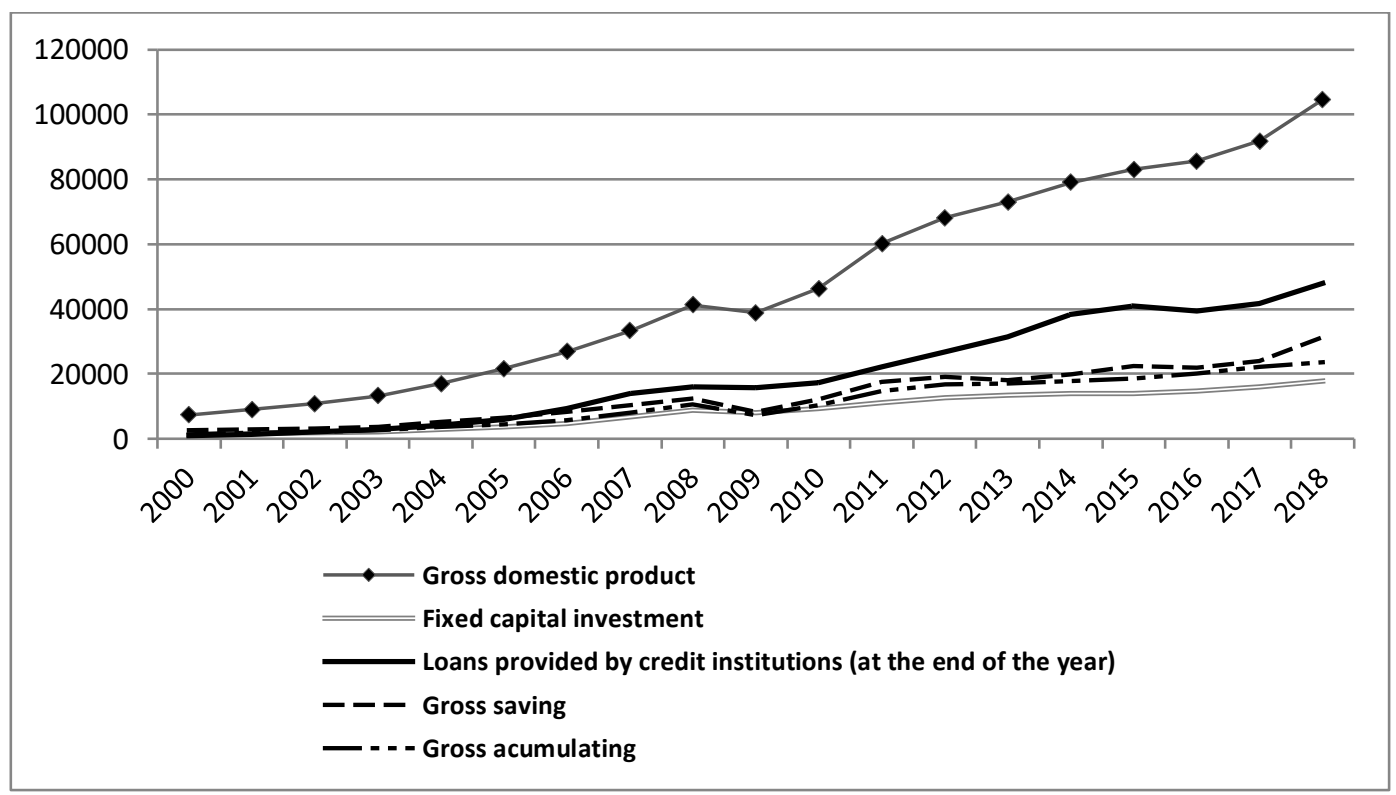

Figure 3. Main macroeconomic indicators in Russian Federation for 2000-2018 (billion rubles) Source: own calculation on the basis of data of Interstate Statistical Committee of the CIS.

In order to confirm this hypothesis, at the fifth stage of the study a correlation-regression analysis of the dependence of economic growth and investment indicators on loans was carried out using the statistical data of the Russian Federation.
The results obtained allowed the authors to conclude that there is a significant degree of influence of the volume of loans provided by credit institutions on the indicators of economic growth and investment in the Russian Federation (Table 3). 
According to Table 3, the following conclusions can be drawn:

- at increasing lending to 1 billion rubles GDP in Russia would increase by an average of 1.95 billion rubles;

- in the absence of loans provided by credit institutions, the volume of investments in fixed capital would be equal to 0.51 billion rubles, and investments would increase by an average of 0.3 billion rubles, with an increase in the volume of lending by 1 billion rubles;
- with an increase in lending by 1 billion rubles, the savings of the countries would increase by an average by 0.56 billion rubles;

- if the volume of lending increased by 1 billion rubles, gross accumulation would increase by an average of 0.47 billion rubles.

The data presented in Table 3 allow us to conclude that there is a close correlation between the volume of loans and indicators of gross saving (elasticity coefficient 0.85 ) and gross accumulating (elasticity coefficient 0.86 ) which is consistent with the analysis results for the Republic of Belarus.

Table 3. The correlation and regression analysis results of the impact of loans on the main macroeconomic indicators in Russian Federation

\begin{tabular}{lccccc}
\hline \multicolumn{1}{c}{ Exogenous variable } & Equation & $\begin{array}{c}\text { Coefficient of } \\
\text { determination }\end{array}$ & F-criterion & $\begin{array}{c}\text { Darbin- } \\
\text {-Watson } \\
\text { Criterion }\end{array}$ & $\begin{array}{c}\text { Coefficient } \\
\text { of elasticity }\end{array}$ \\
\hline GDP & $Y=398.14+2.62 x_{1}$ & $R^{2}=0.80$ & 367.4 & 1.36 & 0.82 \\
Fixed capital investment & $Y=0.5089+0.0003 x_{1}$ & $R^{2}=0.48$ & 116.17 & 1.49 & 0.76 \\
Gross saving & $Y=957.44+0.56 x_{1}$ & $R^{2}=0.70$ & 206.84 & 1.51 & 0.85 \\
Gross accumulating & $Y=780.73+0.47 x_{1}$ & $R^{2}=0.63$ & 365.73 & 1.68 & 0.86 \\
\hline
\end{tabular}

Source: own calculation on the basis of research results.

\section{Conclusions}

The results of the correlation-regression analysis confirms the existence of links between the studied indicators. The identified interrelationships make it possible to assess the promising directions of coordination of monetary regulation of investments in the Russian Federation and the Republic of Belarus pertaining to the stimulation of mutual investments and economic growth in the Union State. According to the authors, it is advisable to form coordinated actions on the part of the central banks of the two countries in the direction of the joint implementation of forms and methods of stimulating the credit and deposit policy of commercial banks. This presupposes the further improvement and expansion of uniform organizational and institutional conditions in the monetary sphere, the introduction of modern marketing technologies, innovative products and services in the banking systems of the two countries.

\section{References}

Borovikov, V. (2003). STATISTICA. The art of data analysis on a computer. Sankt-Petersburg: Piter.

Burda, M., Viplos, Ch. (1998). Macroeconomics. Sankt-Petersburg: Sudostroenie.
On guarantees of safety of funds of individuals placed on accounts and (or) in bank deposits: Decree of the President of the Republic of Belarus, 29 June 2017 No. 3. Retrieved from http://www.nbrb.by/legislation/documents/d22 3.pdf.

Finances of the Commonwealth of Independent States 2014-2018: Statistical Book (2019). Interstate Statistical Committee of the CIS.

Finances, investments and prices of the Commonwealth of Independent States 2011-2015: Statistical collection. (2016). Interstate Statistical Committee of the CIS.

How are the economies of Belarus and Russia connected? What is important to know? (2020). Retrieved from https://www.rbc.ru/economics/ 19/08/2020/5f3bcfd09a7947dbc3afb76b.

Korishchenko, K.N., Morozov, S.V., Bryanov, G.A. (2018). Impact of monetary policy on the balance of payments and macroeconomic indicators.

Law of the Republic of Belarus. 8 July 2008. No. 369-3. Retrieved from http://www.nbrb.by/ legislation/documents//_369-z.pdf.

Methodology for the formation of income accounts (2017). National Statistical Committee of the Republic of Belarus. Retrieved from https://www.belstat.gov.by/metodologiya/metodi ki-po-formirovaniyu-i-raschetu-statistichesk/. 
National Statistical Committee of the Republic of Belarus. Retrieved from: https://www.belstat. gov.by/ofitsialnaya-statistika/realny-sectorekonomiki/inostrannye-investitsii/.

Navoi, A.V. (2013). Trends in the development of central banks in the context of economic globalization. Retrieved from https://www. dissercat.com/content/tendentsii-razvitiyatsentralnykh-bankov-v-usloviyakhglobalizatsii-ekonomik.

Rekeda, S. (2019) The Union State of Russia and Belarus: Searching for a Development Vector. Retrieved from. https://russiancouncil.ru/en/ analytics-and-comments/analytics/the-unionstate-of-russia-and-belarus-searching-for-adevelopment-vector/.

Rumas, S., Pleshkun, A. (2006). Funds of the population in the resource base of banks. Bulletin of banks (7) 2006: 12-19.
Twenty-five years of the Commonwealth of Independent States 1991-2015: Statistical Book (2016). Interstate Statistical Committee of the CIS.

Yearbook of Banking statistics (2018) National Bank of the Republic of Belarus. Retrieved from http://www.nbrb.by/publications/bulletinyearboo k/statistics_bulletin_yearbook_2018.pdf.

Zelenkevich, M., Bandarenka, N. (2020). Assessment of the impact of monetary factors on the economy of the Republic of Belarus. St. Petersburg: Publishing house of St. Petersburg State University of Economics. 